\title{
Electrophoretic Mobility Shift Assays for RNA-Protein Complexes
}

Donald C. Rio

The electrophoretic mobility shift assay (EMSA), or gel mobility shift assay, is a popular and powerful technique for the detection of RNA-protein interactions. It relies on the fact that naked RNA has certain mobility on nondenaturing gels, but if the RNA is bound by protein, the mobility of the RNA is reduced. Therefore, the binding of protein results in a characteristic upward shift of the RNA on a gel, as monitored using radiolabeled RNA. For reasons that are not completely understood, most RNAprotein complexes-particularly those that result from high-affinity interactions-do not dissociate during the prolonged times required for electrophoretic separation. Because high-affinity interactions are more stable, it is often possible to identify specific interactions over a "background" of weak interactions. Accordingly, EMSAs can be performed using complex mixtures of proteins such as cell extracts. They can be used to investigate a wide range of RNA-protein interactions-from single protein-binding events to assembly of large complexes such as the spliceosome. EMSAs can also be useful for determining kinetic parameters (such as affinity constants) for RNA-protein interactions.

It is essential that you consult the appropriate Material Safety Data Sheets and your institution's Environmental Health and Safety Office for proper handling of equipment and hazardous material used in this protocol.

RECIPES: Please see the end of this protocol for recipes indicated by $<R>$. Additional recipes can be found online at http://cshprotocols.cshlp.org/site/recipes.

Reagents

Acrylamide (40\% stock)

Binding buffer for mobility shift assays $<\mathrm{R}>$

Bisacrylamide (2\% stock)

Bovine serum albumin (BSA)

Bromophenol blue

Glycerol

Heparin $\left(50 \mathrm{mg} / \mathrm{mL}[\mathrm{w} / \mathrm{v}]\right.$ in $\left.\mathrm{H}_{2} \mathrm{O}\right)$ (Sigma-Aldrich $\mathrm{H} 3393$ )

Loading buffer for mobility shift assays $<\mathrm{R}>$

$\mathrm{NaCl}$

Protein of interest (purified protein or cell extract)

See Preparation of Nuclear Extracts from HeLa Cells (Nilsen 2013).

Adapted from RNA: A Laboratory Manual, by Donald C. Rio, Manuel Ares Jr., Gregory J. Hannon, and Timothy W. Nilsen. CSHL Press, Cold Spring Harbor, NY, USA, 2011.

(C) 2014 Cold Spring Harbor Laboratory Press

Cite this protocol as Cold Spring Harb Protoc; doi:10.1101/pdb.prot080721 
D.C. Rio

RNA of interest (uniformly labeled and purified)

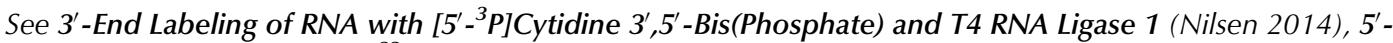
End Labeling of RNA with $\left[\gamma_{-}{ }^{32}\right.$ P]ATP and T4 Polynucleotide Kinase (Rio 2014), and In Vitro Transcription of Labeled RNA: Synthesis, Capping, and Substitution (Nilsen and Rio 2012).

Splicing mix for mobility shift assays $(4 \times)<\mathrm{R}>$

Total RNA or tRNA (10 mg/mL from yeast or Escherichia coli)

Tris (pH 7.6)

Tris/borate/EDTA (TBE) electrophoresis buffer $(10 \times)<\mathrm{R}>$

Tris-glycine buffer $(10 \times)<\mathrm{R}>$

Xylene cyanol

Equipment

Electrophoresis equipment

This should include a vertical gel apparatus; plates $(17 \times 14.7 \times 0.15 \mathrm{~cm})$, comb (with $0.75 \mathrm{~cm}$-wide wells), and spacers (0.8 or $1.5 \mathrm{~mm}$ thick) for pouring gels; and a high-voltage power supply.

Ice

Incubator at appropriate temperature for binding $\left(4^{\circ} \mathrm{C}-37^{\circ} \mathrm{C}\right)$

Microcentrifuge tubes $(1.5 \mathrm{~mL})$

Phosphorimager equipment or X-ray film and intensifying screen

Vacuum gel dryer

Whatman 3MM paper

METHOD

It is important to note that there are a large number of potential variations to gel-shift assays. Thus, the buffers, incubation times and temperatures, nonspecific competitors (see Discussion), and even gel conditions may vary depending on the complexes being studied. Below are example protocols for different types of RNA-protein interactions - from simple interactions (e.g., U1 snRNA and purified U1A protein) and small complexes (e.g., U1 snRNA and its associated proteins) to large multicomponent complexes (e.g., the spliceosome). These are readily adaptable to any situation.

Simple Interactions

1. Label the RNA of interest.

- To label the RNA uniformly with $\left[\alpha_{-}{ }^{32} \mathrm{P}\right] \mathrm{NTP}$, use in vitro transcription (see In Vitro Transcription of Labeled RNA: Synthesis, Capping, and Substitution [Nilsen and Rio 2012]).

- For an oligoribonucleotide or a 100-200-nucleotide purified RNA, end-label using $\left.{ }^{32} \mathrm{P}\right]$ cytidine $3^{\prime}, 5^{\prime}$-bis(phosphate) or $\left[\gamma_{-}{ }^{32} \mathrm{P}\right]$ ATP (see $3^{\prime}$-End Labeling of RNA with $\left[5^{\prime}-{ }^{32} \mathrm{P}\right]$ Cytidine $3^{\prime}, 5^{\prime}$-Bis(Phosphate) and T4 RNA Ligase 1 [Nilsen 2014] and 5'-End Labeling of RNA with $\left[\gamma-{ }^{32} \mathrm{P}\right]$ ATP and T4 Polynucleotide Kinase [Rio 2014]).

2. Incubate the labeled RNA with purified protein under suitable binding conditions (e.g., binding buffer supplemented with $10 \mu \mathrm{g} / \mathrm{mL}$ BSA). For example, mix the following together on ice.

$\begin{array}{lr}\text { Binding buffer (supplemented with } 10 \mu \mathrm{g} / \mathrm{mL} \text { BSA) } & 20 \mu \mathrm{L} \\ \text { RNA (50,000 cpm) } & 1 \mu \mathrm{L} \\ \text { Purified protein (serial dilutions from excess to less than equimolar) } & 4 \mu \mathrm{L}\end{array}$

Incubate the mixture for $30-60 \mathrm{~min}$ at room temperature, $30^{\circ} \mathrm{C}$, or $37^{\circ} \mathrm{C}$.

It is often useful to include controls, such as inhibitors of the interaction and both specific and nonspecific RNA competitors.

3. After incubation, dilute the sample with $4 \mu \mathrm{L}$ of loading buffer (without heparin) and load $10-20 \mu \mathrm{L}$ of the mixture onto a native polyacrylamide gel. For a single protein $(\sim 50,000 \mathrm{MW})$ 
and a single RNA ( $\sim 100$ nucleotides long), start with a $0.8 \mathrm{~mm}$-thick $6 \%$ acrylamide:bisacrylamide (30:1) gel made with Tris-glycine buffer or TBE. Prerun the gel for $30 \mathrm{~min}$.

Try varying the $\mathrm{pH}$ of the gel and buffers. Vary the ratio of Tris to glycine until the optimal $\mathrm{pH}$ is found. The percentage of gel and ratio of acrylamide:bisacrylamide may need to be varied to optimize separation of the bound and free RNA.

Do not overload the wells. For small wells (20-well comb), use a maximum volume of $5 \mu \mathrm{L} / w e l l$.

4. Perform electrophoresis at $300 \mathrm{~V}$ for $3 \mathrm{~h}$ (or $13 \mathrm{~V} / \mathrm{cm}$ ), making sure that it does not heat up. If the interactions are suspected to be unstable, run the gel in a cold room.

5. After the gel is run, use a sheet of Whatman $3 \mathrm{MM}$ paper to pick up the gel. Dry the gel with vacuum at $80^{\circ} \mathrm{C}$. Expose the gel to a phosphorimager or X-ray film.

Longer RNA Forming a Small Complex

1. Prepare a labeled RNA target by in vitro transcription (see In Vitro Transcription of Labeled RNA: Synthesis, Capping, and Substitution [Nilsen and Rio 2012]). Gel-purify the RNA to make sure that the substrate will be a single band on a gel.

2. Incubate the labeled RNA with purified protein under suitable binding conditions. For example, mix the following together on ice.
Binding buffer
$20 \mu \mathrm{L}$
RNA $(50,000 \mathrm{cpm})$
$1 \mu \mathrm{L}$
Purified proteins or cell extract
$1-4 \mu \mathrm{L}$

Incubate for $30-60 \mathrm{~min}$ at the preferred temperature $\left(4^{\circ} \mathrm{C}-37^{\circ} \mathrm{C}\right)$.

It is often useful to include controls, such as inhibitors of the interaction and both specific and nonspecific RNA competitors.

3. Following incubation, dilute the reaction to $100 \mu \mathrm{L}$ with buffer containing $500 \mathrm{~mm} \mathrm{NaCl}, 10 \mathrm{~mm}$ Tris (pH 7.6), 5\% glycerol, and $200 \mu \mathrm{g} / \mathrm{mL}$ heparin (in cases where cellular extract is used). Incubate for $10 \mathrm{~min}$ at room temperature.

Heparin and high salt are included to resolve what could otherwise appear as a radioactive smear into discrete complexes on the gel. However, heparin also likely strips some proteins from the complexes. Total RNA or tRNA might also be added to improve resolution.

4. Remove $1 \mu \mathrm{L}$ of the reaction and add it to $30 \mu \mathrm{L}$ of loading buffer. Make sure that the glycerol concentration is at least $5 \%$ so that the sample does not float away.

5. Load this sample onto a $1.5 \mathrm{~mm}$-thick, $20 \mathrm{~cm}$-long $0.5 \times \mathrm{TBE}, 6 \%$ acrylamide:bisacrylamide (60:1) gel. Perform electrophoresis at $25 \mathrm{~mA}$ until the xylene cyanol is about two-thirds down the gel.

The percentage of gel and ratio of acrylamide:bisacrylamide may need to be varied to optimize separation of the bound and free RNA.

Do not overload the wells. For small wells (20-well comb), use a maximum volume of $5 \mu \mathrm{L} /$ well.

6. Disassemble the gel, pick it up with Whatman $3 \mathrm{MM}$ paper, and dry it at $80^{\circ} \mathrm{C}$. Expose the gel to a phosphorimager or X-ray film.

Large Multicomponent RNA-Protein Complexes

1. Prepare a native gel containing $3.75 \%-4.2 \%$ polyacrylamide and acrylamide:bisacrylamide (80:1).

2. Pour the solution into $17 \times 14.7 \times 0.15 \mathrm{~cm}$ plates, insert a comb with $0.75 \mathrm{~cm}$-wide wells, and allow the gel to polymerize. (This usually takes at least $30 \mathrm{~min}$.)

The gel will be very jelly-like. Narrower wells, such as those in a 20-well comb, can also be used.

3. Mix the following components in a $1.5 \mathrm{~mL}$ microcentrifuge tube by pipetting up and down. 
D.C. Rio

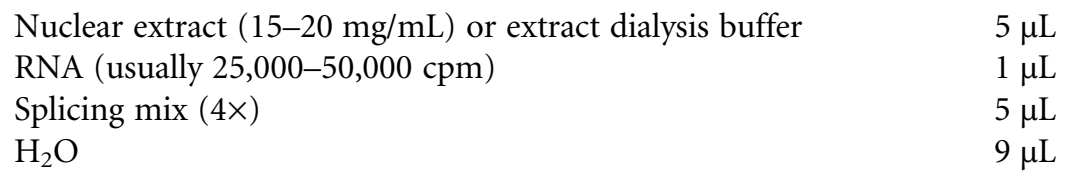

Incubate for $30-60 \mathrm{~min}$ at $20^{\circ} \mathrm{C}-30^{\circ} \mathrm{C}$.

It is often useful to include controls, such as inhibitors of the interaction and both specific and nonspecific RNA competitors.

4. Stop the reaction by placing the tubes on ice. Add heparin (titrate a range between 5 and $500 \mu \mathrm{g} / \mathrm{mL}$ ) to reduce nonspecific binding.

5. Add $3 \mu \mathrm{L}$ of $1 \%$ xylene cyanol and bromophenol blue to the reactions. Mix by pipetting up and down.

Alternatively, the dye can be added to a free lane on the gel to monitor electrophoresis and prevent possible interference with protein binding.

6. Prerun the gel for 20 min at no more than $6 \mathrm{~W}$.

For large protein-RNA assemblies, such as pre-mRNA splicing complexes, it may be useful to try native agarose gels instead of polyacrylamide gels.

7. Load $5 \mu \mathrm{L}$ of the binding reaction mixture from Step 5 onto the gel.

Do not overload the wells. For small wells (20-well comb), use a maximum volume of $5 \mu \mathrm{L} /$ well.

8. Run the gel at no more than $6 \mathrm{~W}$ at $120-210 \mathrm{~V}$ maximum at room temperature until the dye is $1-2 \mathrm{~cm}$ from the bottom (for a 70-nucleotide RNA).

9. Transfer the gel onto Whatman $3 \mathrm{MM}$ filter paper and dry it for $30-60 \mathrm{~min}$ at $80^{\circ} \mathrm{C}$ on a vacuum gel dryer.

10. Expose the gel to X-ray film with an intensifying screen at $-80^{\circ} \mathrm{C}$.

EMSAs are quite versatile and can be used for a wide variety of purposes (see, e.g., Bowers et al. 2006; Das and Reed 1999; Konarska 1989). They can be valuable for determining if a protein of interest is present in a particular preparation of proteins (e.g., cytoplasmic or nuclear extract). In this case, a labeled synthetic RNA would be incubated with the protein preparation. Following nondenaturing gel electrophoresis, the labeled RNA is visualized by phosphorimaging or autoradiography, and the presence of shifted (or not) material is observed. If a gel shift is observed, it is then necessary to determine if the shift resulted from the binding of a protein that has a specific binding site in RNA.

To distinguish between specific and nonspecific binding, competition experiments are performed. If the shift is abolished in the presence of an excess of specific competitor (unlabeled RNA identical to the labeled RNA), but not by an excess of nonspecific competitor (unlabeled unrelated RNA or a mutant version of the labeled RNA), it can be concluded that the observed shift resulted from specific binding.

If specific binding is observed and one suspects that a specific protein is responsible and an antibody is available for that protein, it is possible to perform what is called supershift analysis. Here, the antibody is included in the initial binding incubation before electrophoresis. Binding of the antibody to a complex of interest with the RNA results in a further reduction in mobility of the complex (i.e., a supershift).

Other more complex questions can also be addressed. Mobility shift approaches have been extremely valuable in deciphering the ordered pathway of assembly of large (megadalton) complexes such as the spliceosome. In this case, assembly can be monitored in the presence or absence of an energy source (ATP) or a specific RNP (small nuclear ribonucleoprotein) or auxiliary factor(s). Such an approach is often the method of choice whenever an RNA-protein interaction (or more complex assembly) can be monitored in vitro. 
Although conceptually straightforward, it is important to note that gel composition and percentage as well as electrophoresis conditions can have profound effects on the results obtained. Finally, it is worth noting that gel mobility shift assays can be used to quantitate various kinetic parameters of RNA-protein interactions (Setzer 1999; Goodrich and Kugel 2007), although, of course, pure proteins (or RNPs) are required for such applications.

Binding Buffer for Mobility Shift Assays

\begin{tabular}{lcr} 
Reagent & Quantity (for $10 \mathrm{~mL})$ & Final concentration \\
\hline Tris $(1 \mathrm{M} ; \mathrm{pH} 8.0)$ & $0.4 \mathrm{~mL}$ & $40 \mathrm{mM}$ \\
$\mathrm{KCl}(2 \mathrm{M})$ & $0.15 \mathrm{~mL}$ & $30 \mathrm{mM}$ \\
$\mathrm{MgCl}_{2}(1 \mathrm{M})$ & $10 \mu \mathrm{L}$ & $1 \mathrm{mM}$ \\
$\mathrm{NP} 40(10 \%, \mathrm{w} / \mathrm{v})$ & $10 \mu \mathrm{L}$ & $0.01 \%(\mathrm{w} / \mathrm{v})$ \\
Dithiothreitol $(\mathrm{DTT})(1 \mathrm{~m})$ & $10 \mu \mathrm{L}$ & $1 \mathrm{mM}$ \\
$\mathrm{H}_{2} \mathrm{O}$ or extract & $9.42 \mathrm{~mL}$ &
\end{tabular}

If the proteins or extract used for binding are not in glycerol, add 5\% to the binding buffer. Store indefinitely at $-20^{\circ} \mathrm{C}$.

Loading Buffer for Mobility Shift Assays

Reagent Quantity (for $10 \mathrm{~mL}$ ) Final concentration

$\mathrm{KCl}(2 \mathrm{~m})$

Tris (1 M, pH 7.6)

Glycerol $(50 \%, \mathrm{w} / \mathrm{v})$

Heparin $(50 \mathrm{mg} / \mathrm{mL})$

Xylene cyanol $(0.1 \%, \mathrm{w} / \mathrm{v})$

Bromophenol blue $(0.1 \%$, w/v)

$\mathrm{H}_{2} \mathrm{O}$
$0.3 \mathrm{~mL}$

$0.1 \mathrm{~mL}$

$1 \mathrm{~mL}$

$40 \mu \mathrm{L}$

$1 \mathrm{~mL}$

$1 \mathrm{~mL}$

$6.56 \mathrm{~mL}$
$60 \mathrm{~mm}$

$10 \mathrm{~mm}$

$5 \%(\mathrm{w} / \mathrm{v})$

$200 \mu \mathrm{g} / \mathrm{mL}$

$0.01 \%(\mathrm{w} / \mathrm{v})$

$0.01 \%(\mathrm{w} / \mathrm{v})$

Store at $4^{\circ} \mathrm{C}$. The amount of heparin may need to be adjusted or omitted.

Splicing Mix for Mobility Shift Assays (4×)

Reagent Quantity (for $100 \mu \mathrm{L}$ ) Final concentration $(4 \times)$

Creatine phosphate $(0.2 \mathrm{M})$

$\mathrm{HEPES} / \mathrm{KOH}$ ( $1 \mathrm{~m} ; \mathrm{pH} 7.6)$

$\mathrm{MgCl}_{2}(100 \mathrm{~mm})$

$\operatorname{ATP}(100 \mathrm{~mm})$

Dithiothreitol (100 mM)

$\mathrm{H}_{2} \mathrm{O}$

Prepare fresh for each use. Keep on ice.

$\begin{array}{rr}10 \mu \mathrm{L} & 20 \mathrm{~mm} \\ 8 \mu \mathrm{L} & 80 \mathrm{~mm} \\ 12 \mu \mathrm{L} & 12 \mathrm{~mm} \\ 8 \mu \mathrm{L} & 8 \mathrm{~mm} \\ 40 \mu \mathrm{L} & 40 \mathrm{~mm}\end{array}$

$22 \mu \mathrm{L}$

TBE Electrophoresis Buffer (10×)

\begin{tabular}{lcc} 
Reagent & Quantity (for 1 L) & Final concentration \\
\hline Tris base & $121.1 \mathrm{~g}$ & $1 \mathrm{M}$ \\
Boric acid & $61.8 \mathrm{~g}$ & $1 \mathrm{M}$ \\
EDTA (disodium salt) & $7.4 \mathrm{~g}$ & $0.02 \mathrm{M}$
\end{tabular}

Prepare with RNase-free $\mathrm{H}_{2} \mathrm{O}$. Dilute $100 \mathrm{~mL}$ to $1 \mathrm{~L}$ to make gel running buffer. Store for up to $6 \mathrm{mo}$ at room temperature. 
D.C. Rio

Tris-Glycine Buffer (10×)

\section{Reagent}

Tris base $(1 \mathrm{M})$

Glycine $(1 \mathrm{M})$

Store at $4^{\circ} \mathrm{C}$. The $\mathrm{pH}$ should be $\sim 8.8$.
Quantity (for 1 L)

$500 \mathrm{~mL}$

$500 \mathrm{~mL}$

$5 \mathrm{M}$

$0.5 \mathrm{M}$

$0.5 \mathrm{M}$

\section{Final concentration}

\section{REFERENCES}

Bowers HA, Maroney PA, Fairman ME, Kastner B, Lührmann R, Nilsen TW, Jankowsky E. 2006. Discriminatory RNP remodeling by the DEAD-box protein DED1. RNA 12: 903-912.

Das R, Reed R. 1999. Resolution of the mammalian E complex and the ATPdependent spliceosomal complexes on native agarose mini-gels. RNA 5: 1504-1508.

Goodrich JA, Kugel JF. 2007. Binding and kinetics for molecular biologists Cold Spring Harbor Laboratory Press, Cold Spring Harbor, NY.

Konarska MM. 1989. Analysis of splicing complexes and small nuclear ribonucleoprotein particles by native gel electrophoresis. Methods Enzymol 180: 442-453.

Nilsen TW. 2013. Preparation of nuclear extracts from HeLa cells. Cold Spring Harb Protoc doi:10.1101/pdb.prot075176.
Nilsen TW. 2014. $3^{\prime}$-End labeling of RNA with $\left[5^{\prime}-{ }^{32} \mathrm{P}\right]$ cytidine $3^{\prime}, 5^{\prime}$-bis (phosphate) and T4 RNA ligase 1. Cold Spring Harb Protoc doi:10.1101/pdb.prot080713.

Nilsen TW, Rio DC. 2012. In vitro transcription of labeled RNA: Synthesis, capping, and substitution. Cold Spring Harb Protoc doi:10.1101/pdb. prot072066.

Rio DC. 2014. $5^{\prime}$-End labeling of RNA with $\left[\gamma_{-}{ }^{32} \mathrm{P}\right] \mathrm{ATP}$ and T4 polynucleotide kinase. Cold Spring Harb Protoc doi:10.1101/pdb. prot080739.

Setzer DR. 1999. Measuring equilibrium and kinetic constants using gel retardation assays. Methods Mol Biol 118: 115-128. 


\section{Electrophoretic Mobility Shift Assays for RNA-Protein Complexes}

Donald C. Rio

Cold Spring Harb Protoc; doi: 10.1101/pdb.prot080721

\begin{tabular}{rc}
$\begin{array}{r}\text { Email Alerting } \\
\text { Service }\end{array}$ & Receive free email alerts when new articles cite this article - click here. \\
\hline $\begin{array}{c}\text { Subject } \\
\text { Categories }\end{array}$ & Browse articles on similar topics from Cold Spring Harbor Protocols. \\
& $\begin{array}{c}\text { Electrophoresis, general (130 articles) } \\
\text { RNA (317 articles) } \\
\text { RNA, general (269 articles) }\end{array}$ \\
\hline
\end{tabular}

